\title{
Response of Bambara groundnut (Vigna subterranean L.) and Maize (Zea mays L.) to heavy metal stress
}

\author{
E. O. Oladele ${ }^{1 *}$, O. O. Adewumi ${ }^{1}$, T. Yahaya ${ }^{2}$ and I. A. Taiwo ${ }^{3}$
}

\begin{abstract}
Background: Plants are usually the target of environmental pollution. This study, therefore, investigates the effects of Zinc (Zn) and lead Pb on Bambara nut (Vigna subterranean) and Maize (Zea mays) at different concentrations, as well as the possible ameliorating effect of the chelant; ethylene diamine acetate (EDTA) and farmyard manure, on the enzymatic activities, the chlorophyll, total protein, and carbohydrate contents.

Results: Findings revealed that $\mathrm{Pb}$ and $\mathrm{Zn}$ increased the superoxide dismutase (SOD), peroxidase, glutathione synthetase (GSH), malondialdehyde (MDA), and catalase levels with increased concentrations from $100 \mathrm{mg} / \mathrm{kg}$ to $200 \mathrm{mg} / \mathrm{kg}$ significantly $(p<0.05)$ compared to the control Maize plants. While in Bambara nut, the superoxide dismutase (SOD), peroxidase, glutathione synthetase (GSH), and catalase levels decreased with increased concentrations from $100 \mathrm{mg} / \mathrm{kg}$ to $200 \mathrm{mg} / \mathrm{kg}$ compared to control except for the malondialdehyde (MDA) which was increased. For Bambara groundnut, with increased $\mathrm{Pb}$ concentrations, the chlorophyll content reduced from 2.94 to $2.00 \mathrm{mg} / \mathrm{g}$. However, there was an increase (up to $4.918 \mathrm{mg} / \mathrm{g}$ ) in the chlorophyll content with increased zinc nitrate concentrations augmented with EDTA at the highest concentration. Maize plants treated with Pb augmented with farmyard manure showed an increase in chlorophyll content with increased concentrations while those assisted with EDTA still experienced a decrease as metal concentrations increased. Bambara groundnut plant had a mean carbohydrate (\%) of 14.79 (control), 17.60 (100 mg/kg of Pb concentration) and 11.20 (200 mg/kg of Pb concentration), indicating a decrease in carbohydrate content with increased $\mathrm{Pb}$ concentrations. The same trend was observed for the different $\mathrm{Zn}$ and $\mathrm{Pb}$ concentrations on the mean total proteins and carbohydrates of both test plants. Generally, Pb and $\mathrm{Zn}$ induced oxidative stress in treated plants.
\end{abstract}

Conclusions: Elevated activity of anti-oxidative enzymes can assist as important components of antioxidative defense mechanism against oxidative damage. The results of this study could be beneficial in the understanding of the role of the defense system as well as the detoxification mechanism of Vigna subterranean and Zea mays in efficient tolerance and response to $\mathrm{Pb}$ and $\mathrm{Zn}$. This signifies that these plants can act as bioindicators in environmental quality assessment.

Keywords: Heavy metals, Superoxide dismutase (SOD), Phytochelatins, Glutathione synthetase (GSH), Malondialdehyde (MDA)

\footnotetext{
* Correspondence: eoladele@unilag.edu.ng

${ }^{1}$ Biology Unit, Distance Learning Institute, University of Lagos, Akoka, Lagos,

Nigeria

Full list of author information is available at the end of the article
} 


\section{Background}

Environmental pollution by toxic metals usually occurs due to various industrial activities [46]. There are so many adverse effects of toxic metals already reported. In all these reports, heavy metal toxicity has been the greatest threat. Plants are usually the target of a wide range of pollutants that vary in concentration speciation and toxicity. According to Arshad et al. [9], such pollutants enter the plant system through the soil and through the atmosphere [43]. It is important to note that among common pollutants that affect plants, lead is one of the most toxic and frequently encountered [21, 38, 42]. According to Maestri et al. [29], lead ( $\mathrm{Pb}$ ) has no known biological function in living organisms and has been recognized as a chemical of great concern in the new European REACH regulations (EC 1907/2006; Registration, Evaluation, Authorization, and Restriction of Chemicals). Agency for Toxic substances and Disease Registry [10] reported lead as being the second most hazardous substance after arsenic due to its frequency of occurrence, toxicity, and potential for human exposure. Lead is very abundant on earth and exposure to it has led to several environmental and occupational health hazards [47]. Report by Niazi et al. [34] shows that toxic metal (including lead and zinc) uptake by vegetables causes human exposure to environmental pollutants.

Legumes (family Fabales) develop root nodules that harbor Rhizobium bacteria (rhizobia). Endosymbiotic bacteria (bacteroids) are able to convert nitrogen to ammonia, i.e, (biological nitrogen fixation). Symbiosis is based on metabolic exchange for mutual benefit: exchanges of oxygen, carbon, and nitrogen are rightly regulated. Legumes only form a nitrogen-fixing symbiosis with single-celled bacteria collectively termed Rhizobium. The legume-Rhizobium symbiosis provides onefifth of all nitrogen inputs into global agriculture. Legume crops bring back fertility to agricultural soils by capturing nitrogen from the atmosphere.

Maize (Zea mays L.), is a temperate and subtropical cereal crop that can withstand so many stress. Maize varieties have been observed to show varying adaptability to different abiotic stress despite being an important cereal for both man and animal consumption. Maize is a cereal crop cultivated for food and industrial purposes [41]. In Nigeria, Maize is well known as one of the main staple food [36]. It is a very important source of carbohydrate, in which the yellow grain contains a useful quantity of vitamin A [2].

Zinc is known as an important element for plant nutrition. It plays structural and/or catalytic roles in many enzymes such as $\mathrm{Cu}-\mathrm{Zn}$ superoxide dismutase, alcohol dehydrogenase, RNA polymerase and DNA-binding proteins [25]. It should be noted that when zinc is massively present in the environment, it can reach supraoptimal concentrations in all plant organs, thereby inducing toxic effects and metabolic disorders. Baccio et al. [12] reported that zinc becomes toxic at high concentration levels and can lead to stress in plants. Oxidative stress has been known to represent an imbalance between the production of reactive oxygen species and a biological system's ability to readily detoxify the reactive intermediates or to repair the resulting damage [4, 14]. SOD enzymes are present in almost all aerobic cells and in extracellular fluids. Catalase is responsible for the conversion of hydrogen peroxide to water and oxygen, using either an iron or manganese cofactor [25]. According to Alscher et al. [3] and Niazi et al. [34], protection against oxidative damage is usually done by an antioxidative system that has the enzymes and nonenzymes. Normally, plant cells are known to use the ascorbate-glutathione pathway to reduce the accumulation of oxygen-free radicals [33]. At the end of the reaction, glutathione and glutathione reductase regenerates ascorbate [35]. It is important to note that low molecular weight compounds like glutathione and carotenoids among others have a very important role to play in the plant defense system [37]. In view of all these, it is essential to understand the interactive effects resulting from combinations of metal ions at different concentrations on the enzymatic activities. The study also investigated the possible ameliorating effect of the chelant; ethylene diamine acetate (EDTA) and farmyard manure on heavy metal uptake and toxicity on the chlorophyll, total protein, and total carbohydrate content within the leaves of tested legume and cereal plants.

\section{Methods}

\subsection{Materials collection and experimental design}

Dry seeds of Bambara groundnut (Vigna subterranean) and Maize (Zea mays) were collected from the International Institute of Tropical Agriculture (I.I.T.A) Ibadan, Nigeria. The study was done in three locations. The seeds were subjected to a viability test using the floatation technique according to Agbogidi [1]. The seeds were surface-sterilized in $10^{-3} \mathrm{M}$ $\mathrm{HgCl}_{2}$ for $2 \mathrm{~min}$ [11], washed in distilled water, and sown in different pots. The seedlings were irrigated with various concentrations of $\mathrm{Pb}$ and $\mathrm{Zn}(100,150$, and $\left.200 \mathrm{mg} \mathrm{kg}^{-1}\right)$ as $\mathrm{Pb}\left(\mathrm{NO}_{3}\right)^{2}$ and $\mathrm{Zn}\left(\mathrm{NO}_{3}\right)^{2}$ twice a day for 12 weeks. These doses were decided on the basis of LD-50 and the regulatory limits. For the assessment of heavy metals effect on tested plants, based on proximate analysis and chlorophyll content determination, the soil was also augmented with ethylene diamine acetate (EDTA) and farmyard manure to possibly lessen the toxic effect of heavy metals. 


\subsection{Experimental description}

The soil was mixed thoroughly and then filled into 60 black cellophane bags. Four thousand grams $(4 \mathrm{~kg})$ of soil were placed in each bag. The bags were arranged in four rows designated as control (untreated soil) and soil with metals. The experiment was carried out under a period of 90 days [48].

\subsection{Heavy metal determination in the plant samples} The plant samples were digested with concentrated $\mathrm{HNO}_{3}+\mathrm{HClO}_{4}$ following a modified method described by Lone et al. (2008). The samples were analyzed for lead $(\mathrm{Pb})$ and zinc $(\mathrm{Zn})$ accumulation $\left(\mathrm{mg} \mathrm{kg}^{-1} \mathrm{DW}\right)$ using Atomic Absorption Spectrometer (AAS) [28].

\subsection{Determination of superoxide dismutase SOD activity}

The level of determination of superoxide dismutase (SOD) activity in the control and treated plant samples were determined by the method of Magwere et al. [30]. Superoxide dismutase was assayed by monitoring the inhibition of photochemical reaction into nitro blue tetrazolium (NBT). A unit of SOD activity is expressed as the amount of enzyme required to cause $50 \%$ inhibition in the reduction of nitro blue tetrazolium (NBT) at 560 nm.

\subsection{Determination of GSH activity}

The total sulphydryl groups, protein-bound sulphydryl groups, and free sulphydryl groups like glutathione (GSH) in biological samples was determined using Ellman's reagent, 5,5'-dithio-bis-2-nitrobenzoic acid (DTNB) according to the modified method by Jollow et al [26]. Fresh leaf tissue $(1 \mathrm{~g})$ was ground in potassium phosphate buffer $950 \mathrm{Mm}$; pH 7) containing EDTA (1 $\mathrm{mM}$ ) and insoluble PVP (2\%). The homogenate was centrifuged for $10 \mathrm{~min}$ at $15,000 \mathrm{~g}$ and the supernatant was used as enzyme extract.

\subsection{Determination of CAT activity}

Catalase (CAT) activity of the control and treated plant samples were determined according to the method of Sinha [40] but modified by Artenie et al. [8]. Different amounts of $\mathrm{H}_{2} \mathrm{O}_{2}$ ranging from 20 to 160 moles were taken in small test tubes and $2 \mathrm{ml}$ of dichromate/acetic acid was added to each. The addition of the reagents instantaneously produces an unstable blue precipitate of perchromic acid. Subsequent heating for $10 \mathrm{~min}$ in a boiling water bath changed the color of the solution to stable green due to the formation of chromic acetate. After cooling at room temperature, the volume of the reaction mixture was made to $3 \mathrm{ml}$ with distilled water and the absorbance measured with a spectrophotometer at $570 \mathrm{~nm}$.

\subsection{Determination of product of lipid peroxidation (MDA)}

This was assayed by measuring the TBA (thiobarbituric acid), reactive products present in the treated and untreated plant samples using the procedure of Vashney and Kale [44] and expressed as micromolar of malondialdehyde (MDA)/g tissue. Lipid peroxidation was measured in terms of malondialdehyde (MDA) content. An aliquot of $0.4 \mathrm{ml}$ of the test sample was mixed with 1.6 $\mathrm{ml}$ of Tris $\mathrm{KCl}$ buffer (which was first placed into the test tube before the test sample). Then, $0.5 \mathrm{ml}$ of $30 \%$ TCA (Trichloroacetic acid) was added followed by 0.5 $\mathrm{ml}$ of $0.75 \%$ TBA (Thiobarbituric acid) and the mixture was placed in a water bath for 1 hour between $90-95{ }^{\circ} \mathrm{C}$. This was then cooled in ice and centrifuged at 3000 rpm. for $15 \mathrm{~min}$. The clear pink supernatant was collected and absorbance measured against a reference blank of distilled water at $532 \mathrm{~nm}$ in a spectrophotometer.

\subsection{Determination of chlorophyll content in treated and untreated plant samples}

The leaf total chlorophyll content (\%) was evaluated. The chlorophyll content of the seedling was determined using the method of Arnon [7]. Leaves from plants from each treatment and the control were separately put in a clean mortar, $10 \mathrm{ml}$ of $80 \%$ acetone was added and the leaf tissue was ground to fine pulp for $3 \mathrm{~min}$. The resulting green liquid was carefully transferred into a Buchner funnel containing a pad of Whatman No. 1 filter paper. The optical density (OD) of the chlorophyll extract was determined with a spectrophotometer at $663 \mathrm{~nm}$ and $645 \mathrm{~nm}$ against a 100\% acetone solvent blank. (Perkin Elmer UV/VIS Lambda Bio Spectrophotometer)

\subsection{Proximate analysis}

The following parameters were determined for the proximate analysis using the leaves:

Total carbohydrates were determined, after hydrolysis, colorimetrically using anthrone reagent (Fales, [20]). Total carbohydrate contents were measured using the phenol-sulfuric acid assay and using glucose as a standard following the method described by DuBois et al. [18].

Total protein was obtained by determining the organic nitrogen content of the sample using the method by Gopal and Rizvi [22] and multiplying the \% nitrogen by a protein conversion factor which is usually 6.25 [27]. Using the method described by Gopal and Rizvi [22], total protein was colorimetrically measured at $540 \mathrm{~nm}$ against blank using spectrophotometer.

\subsection{Statistical analysis}

All data collected were analyzed using standard deviation, $t$ test, and analysis of variance (ANOVA) for 
statistical significance at 95\% confidence interval. Descriptive statistics were calculated using the Microcal origin 5.0 and Microsoft Excel. Graphical illustrations were also carried out to get a vivid representation of the data obtained.

\section{Results}

Table 1 shows the effects of lead and zinc treatments on superoxide dismutase (SOD), peroxidase, glutathione (GSH), catalase activity, and the level of malondialdehyde (MDA) in Maize. $\mathrm{Zn}$ and $\mathrm{Pb}$ treatment significantly increased the activities of CAT, peroxidase enzymes, and the level of MDA compared to control $(P<0.05)$ in Maize. With increased zinc concentration, the GSH activity increased with a significant difference from the untreated plants $(P<0.05)$. Also, at the highest $\mathrm{Pb}$ concentration of $200 \mathrm{mg} / \mathrm{kg}$, the GSH activity reduced with a significant difference compared to the untreated plants $(P<0.05)$. The SOD activity was also raised with increased zinc concentration with significant difference $(P<0.05)$ compared to control. However, at the lowest $\mathrm{Pb}$ and $\mathrm{Zn}$ concentrations of $100 \mathrm{mg} / \mathrm{kg}$, there was no significant difference $(P>0.05)$ in the SOD level compared to control. At the highest lead concentration, the SOD level observed was significantly higher than the control $(P<0.05)$.

Table 2 shows the effect of lead and zinc treatment on superoxide dismutase (SOD), peroxidase, glutathione (GSH), catalase activities, and the level of malondialdehyde (MDA) in Bambara groundnut. $\mathrm{Zn}$ and $\mathrm{Pb}$ treatment significantly decreased enzyme activity compared to control $(P<0.05)$ except for the MDA in Bambara nut treated with $100 \mathrm{mg} / \mathrm{kg}$ zinc nitrate. The SOD and catalase activities were significantly reduced, while the MDA increased.

\subsection{Chlorophyll content}

Table 3 shows the effects of the different concentrations of the metals on the total chlorophyll content of treated plants. The chlorophyll content $(\mathrm{mg} / \mathrm{g})$ of treated plants decreased significantly with increased lead and zinc concentrations in all treated plants. The chlorophyll contents of all treated plants were affected significantly at all concentrations. The higher concentration of metals decreased the quantity of total chlorophyll of plants significantly $(P<$ 0.05) when compared to the untreated (control) plants. For Bambara groundnut, with increased $\mathrm{Pb}$ concentrations the chlorophyll content reduced. However, there was an increase in the chlorophyll content with increased zinc nitrate concentrations augmented with EDTA. Maize plants treated with $\mathrm{Pb}$ augmented with farmyard manure showed an increase in chlorophyll content as concentrations of $\mathrm{Pb}$ increased while those assisted with EDTA still experienced a decrease rather than an increase in chlorophyll contents as the metal concentrations increased. The untreated (control) Bambara groundnut plant had mean total chlorophyll (mg/g) of $1.598 \pm 0.001$, and Bambara groundnut treated with $100 \mathrm{mg} / \mathrm{kg}$ of lead nitrate had a mean total chlorophyll $(\mathrm{mg} / \mathrm{g})$ of $2.944 \pm 0.952$ and the plant treated with $200 \mathrm{mg} / \mathrm{kg}$ of lead concentration had mean total chlorophyll $(\mathrm{mg} / \mathrm{g})$ of $2.002 \pm 0.616$. Bambara groundnut plants with $200 \mathrm{mg} / \mathrm{kg}$ of $\mathrm{Pb}$ augmented with EDTA gave mean chlorophyll content $(\mathrm{mg} / \mathrm{g})$ of $2.193 \pm$ 0.117 , while the $200 \mathrm{mg} / \mathrm{kg}$ of $\mathrm{Pb}$ augmented with manure gave $5.418 \pm 0.145$. Maize control plants had a mean chlorophyll content of $2.350 \pm 0.03(\mathrm{mg} / \mathrm{g})$. Maize treated with $100 \mathrm{mg} / \mathrm{kg}$ and $200 \mathrm{mg} / \mathrm{kg}$ of $\mathrm{Pb}$ concentration had mean chlorophyll content $(\mathrm{mg} / \mathrm{g})$ of $1.242 \pm 0.02$ and $1.092 \pm 0.01$, respectively. Maize plants treated with 200 $\mathrm{mg} / \mathrm{kg}$ of $\mathrm{Pb}$ augmented with EDTA gave mean chlorophyll content $(\mathrm{mg} / \mathrm{g})$ of $1.876 \pm 0.02$, while the plant treated with $200 \mathrm{mg} / \mathrm{kg}$ of $\mathrm{Pb}$ augmented with manure gave $1.621 \pm 0.04(\mathrm{mg} / \mathrm{g})$. Maize plants treated with $\mathrm{Zn}$ augmented with farmyard manure showed an increase in chlorophyll content as concentrations of $\mathrm{Zn}$ increased while those assisted with EDTA still experienced a decrease rather than an increase in chlorophyll contents as the metal concentrations increased. The untreated (control) Bambara groundnut plant had mean total chlorophyll $(\mathrm{mg} / \mathrm{g})$ of $1.598 \pm 0.001$, Bambara groundnut treated with

Table 1 Impact of different concentrations of Lead and Zinc nitrates on some Enzymes and Lipid Peroxidation in maize

\begin{tabular}{llllll}
\hline Treatment & SOD $(\mathrm{U} / \mathrm{mg})$ & $\begin{array}{l}\text { PEROXIDASE } \\
(\mathrm{U} / \mathrm{mg})\end{array}$ & GSH $(\mu \mathrm{mole} / \mathrm{min} / \mathrm{mg})$ & CAT $(\mathrm{U} / \mathrm{mg})$ & MDA $(\mathrm{U} / \mathrm{mg})$ \\
\hline Control & $0.75 \pm 0.03$ & $18.20 \pm 0.15$ & $0.26 \pm 0.08$ & $16.54 \pm 0.44$ & $0.008 \pm 0.002$ \\
$100 \mathrm{mg} / \mathrm{kg}$ lead & $0.78 \pm 0.02$ & $17.58 \pm 0.10^{*}$ & $0.08 \pm 0.03^{*}$ & $24.43 \pm 0.37^{*}$ & $0.118 \pm 0.018^{*}$ \\
$150 \mathrm{mg} / \mathrm{kg}$ lead & $0.98 \pm 0.22^{*}$ & $22.20 \pm 0.27^{*}$ & $0.12 \pm 0.02^{*}$ & $27.54 \pm 0.37^{*}$ & $0.310 \pm 0.02$ \\
$200 \mathrm{mg} / \mathrm{kg}$ lead & $1.10 \pm 0.11^{*}$ & $26.10 \pm 0.50^{*}$ & $0.17 \pm 0.02^{*}$ & $30.42 \pm 0.07^{*}$ & $0.430 \pm 0.04^{*}$ \\
$100 \mathrm{mg} / \mathrm{kg}$ zinc & $0.82 \pm 0.06$ & $23.40 \pm 0.25^{*}$ & $0.18 \pm 0.04^{*}$ & $22.21 \pm 0.30^{*}$ & $0.080 \pm 0.02^{*}$ \\
$150 \mathrm{mg} / \mathrm{kg}$ zinc & $2.77 \pm 0.24^{*}$ & $46.40 \pm 0.15^{*}$ & $0.21 \pm 0.07^{*}$ & $72.10 \pm 0.12^{*}$ & $0.202 \pm 0.005^{*}$ \\
$200 \mathrm{mg} / \mathrm{kg}$ zinc & $2.98 \pm 0.45^{*}$ & $52.20 \pm 0.44^{*}$ & $0.30 \pm 0.03^{*}$ & $76.22 \pm 0.15^{*}$ & $0.345 \pm 0.015^{*}$ \\
\hline
\end{tabular}

The values are the means + SEM (range) of 3 replicates

When ${ }^{*} P<0.05=$ significantly different from control

When $P>0.05=$ not significantly different from control 
Table 2 Impact of different concentrations of lead and zinc nitrate on some enzymes and lipid peroxidation in Bambara nut

\begin{tabular}{llllll}
\hline Treatment & SOD $(\mathrm{U} / \mathrm{mg})$ & $\begin{array}{l}\text { PEROXIDASE } \\
(\mathrm{U} / \mathrm{mg})\end{array}$ & $\begin{array}{l}\text { GSH } \\
(\mu \mathrm{mole} / \mathrm{min} / \mathrm{mg})\end{array}$ & CAT (U/mg) & MDA (U/mg) \\
\hline Control & $2.57 \pm 0.05$ & $53.42 \pm 0.83$ & $0.45 \pm 0.03$ & $72.42 \pm 0.39$ & $0.033 \pm 0.007$ \\
$100 \mathrm{mg} / \mathrm{kg}$ lead & $1.00 \pm 0.03^{*}$ & $38.48 \pm 0.53^{*}$ & $0.12 \pm 0.03^{*}$ & $40.08 \pm 0.24^{*}$ & $0.068 \pm 0.005^{*}$ \\
$150 \mathrm{mg} / \mathrm{kg} \mathrm{lead}$ & $0.72 \pm 0.02^{*}$ & $20.86 \pm 0.14^{*}$ & $0.09 \pm 0.02^{*}$ & $20.35 \pm 0.35^{*}$ & $0.071 \pm 0.002^{*}$ \\
$200 \mathrm{mg} / \mathrm{kg}$ lead & $0.68 \pm 0.05^{*}$ & $20.10 \pm 0.14^{*}$ & $0.06 \pm 0.01^{*}$ & $18.65 \pm 0.35^{*}$ & $0.092 \pm 0.002^{*}$ \\
$100 \mathrm{mg} / \mathrm{kg}$ zinc & $1.86 \pm 0.05^{*}$ & $51.44 \pm 0.05^{*}$ & $0.41 \pm 0.02^{*}$ & $66.78 \pm 0.12^{*}$ & $0.029 \pm 0.011$ \\
$150 \mathrm{mg} / \mathrm{kg}$ zinc & $1.69 \pm 0.05^{*}$ & $48.40 \pm 0.55^{*}$ & $0.38 \pm 0.02^{*}$ & $64.38 \pm 0.29^{*}$ & $0.038 \pm 0.002^{*}$ \\
$200 \mathrm{mg} / \mathrm{kg}$ zinc & $1.22 \pm 0.04^{*}$ & $44.30 \pm 0.40^{*}$ & $0.29 \pm 0.03^{*}$ & $54.34 \pm 0.09^{*}$ & $0.082 \pm 0.002^{*}$ \\
\hline
\end{tabular}

The values are the means + SEM (range) of 3 replicates

When ${ }^{*} P<0.05=$ significantly different from control

When $P>0.05=$ not significantly different from control

$100 \mathrm{mg} / \mathrm{kg}$ of zinc nitrate had a mean total chlorophyll $(\mathrm{mg} / \mathrm{g})$ of $3.649 \pm 0.13$ and the plant treated with $200 \mathrm{mg} /$ $\mathrm{kg}$ of $\mathrm{Zn}$ concentration had mean total chlorophyll $(\mathrm{mg} / \mathrm{g})$ of $3.112 \pm 0.06$. Bambara groundnut plants with $200 \mathrm{mg} /$ $\mathrm{kg}$ of $\mathrm{Zn}$ augmented with EDTA gave mean chlorophyll content $(\mathrm{mg} / \mathrm{g})$ of $4.918 \pm 0.21$, while the $200 \mathrm{mg} / \mathrm{kg}$ of $\mathrm{Zn}$ augmented with manure gave $5.816 \pm 0.16$. Maize control plants had a mean chlorophyll content of $2.350 \pm 0.03$ $(\mathrm{mg} / \mathrm{g})$. Maize treated with $100 \mathrm{mg} / \mathrm{kg}$ and $200 \mathrm{mg} / \mathrm{kg}$ of Zn concentration had mean chlorophyll content $(\mathrm{mg} / \mathrm{g})$ of $1.565 \pm 0.04$ and $1.352 \pm 0.03$, respectively. Maize plants treated with $200 \mathrm{mg} / \mathrm{kg}$ of $\mathrm{Zn}$ augmented with EDTA gave mean chlorophyll content $(\mathrm{mg} / \mathrm{g})$ of $3.989 \pm 0.07$, while the plant treated with $200 \mathrm{mg} / \mathrm{kg}$ of $\mathrm{Zn}$ augmented with manure gave $6.101 \pm 0.15(\mathrm{mg} / \mathrm{g})$.

\subsection{Proximate analysis}

\subsubsection{Total carbohydrate and total protein}

Tables 4 and 5 show the effects of different Lead and Zinc concentrations on the total protein and total carbohydrates. The total protein and total carbohydrate of treated plants decreased significantly with increased lead and zinc concentrations. For Maize, whether assisted with chelator and manure or not, the protein and carbohydrate contents decreased significantly with increased lead and zinc concentrations. However, farmyard manure assisted Bambara groundnut when planted in soil with the lowest lead concentrations of $100 \mathrm{mg} / \mathrm{kg}$ and different zinc nitrate concentrations. They had higher percentages of protein and carbohydrates compared with the mean values observed for their control plants. When the Bambara groundnut was planted in soil containing the lowest concentration of lead and mixed with EDTA, a high-percentage carbohydrate was also observed. Control Bambara groundnut plant had a mean carbohydrate (\%) of $14.79 \pm 0.09,17.60 \pm 0.01$ for $100 \mathrm{mg} / \mathrm{kg}$ of lead concentration and $11.20 \pm 0.02$ for $200 \mathrm{mg} / \mathrm{kg}$ of lead concentration, indicating a decrease in carbohydrate content with increased concentrations. Bambara groundnut plants with $100 \mathrm{mg} / \mathrm{kg}$ of lead and EDTA gave a mean percentage carbohydrate of $15.57 \pm 0.08$,

Table 3 Impact of lead concentrations on total chlorophyll $(\mathrm{mg} / \mathrm{g})$ of the test plants

\begin{tabular}{|c|c|c|c|c|}
\hline Plants/concentration & $\begin{array}{l}\text { Bambara groundnut } \\
\text { (Pb treatment) } \\
\text { Mean value } \pm \text { SEM }\end{array}$ & $\begin{array}{l}\text { Maize } \\
\text { (Pb treatment) } \\
\text { Mean value } \pm \text { SEM }\end{array}$ & $\begin{array}{l}\text { Bambara groundnut } \\
\text { (Zn treatment) } \\
\text { Mean value } \pm \text { SEM }\end{array}$ & $\begin{array}{l}\text { Maize } \\
\text { (Zn treatment) } \\
\text { Mean value } \pm \text { SEM }\end{array}$ \\
\hline Control & $1.598 \pm 0.001$ & $2.350 \pm 0.03$ & $1.598 \pm 0.001$ & $2.350 \pm 0.03$ \\
\hline 100 mg/kg & $2.944 \pm 0.952^{*}$ & $1.242 \pm 0.02^{*}$ & $3.649 \pm 0.13^{*}$ & $1.565 \pm 0.04^{*}$ \\
\hline $150 \mathrm{mg} / \mathrm{kg}$ & $2.418 \pm 0.202^{*}$ & $1.108 \pm 0.02^{*}$ & $3.501 \pm 0.1^{*}$ & $1.486 \pm 0.05^{*}$ \\
\hline 200 mg/kg & $2.002 \pm 1.616^{*}$ & $1.092 \pm 0.01^{*}$ & $3.112 \pm 0.06^{*}$ & $1.352 \pm 0.03^{*}$ \\
\hline $100 \mathrm{mg} / \mathrm{kg}+$ EDTA & $2.872 \pm 0.618^{*}$ & $2.028 \pm 0.03^{*}$ & $3.712 \pm 0.09^{*}$ & $4.141 \pm 0.10^{*}$ \\
\hline $150 \mathrm{mg} / \mathrm{kg}+$ EDTA & $2.648 \pm 0.320^{*}$ & $1.912 \pm 0.12^{*}$ & $4.518 \pm 0.10^{*}$ & $4.102 \pm 0.11^{*}$ \\
\hline $200 \mathrm{mg} / \mathrm{kg}+$ EDTA & $2.193 \pm 0.117^{*}$ & $1.876 \pm 0.02^{*}$ & $4.918 \pm 0.21^{*}$ & $3.989 \pm 0.07^{*}$ \\
\hline 100 mg/kg + manure & $5.712 \pm 0.100^{*}$ & $1.308 \pm 0.01^{*}$ & $4.612 \pm 0.09^{*}$ & $5.122 \pm 0.11^{*}$ \\
\hline 150 mg/kg + manure & $5.528 \pm 0.150^{*}$ & $1.475 \pm 0.03^{*}$ & $5.622 \pm 0.18^{*}$ & $5.893 \pm 0.06^{*}$ \\
\hline $200 \mathrm{mg} / \mathrm{kg}+$ manure & $5.418 \pm 0.145^{*}$ & $1.621 \pm 0.04^{*}$ & $5.816 \pm 0.16^{*}$ & $6.101 \pm 0.15^{*}$ \\
\hline
\end{tabular}

The values are the means + SEM (range) of 3 replicates

When ${ }^{*} P<0.05=$ significantly different from control

When $P>0.05=$ not significantly different from control 
Table 4 Effect of lead and zinc concentration on the total carbohydrate of the test plants

\begin{tabular}{|c|c|c|c|c|}
\hline \multirow[t]{3}{*}{ Plants/concentration } & Bambara groundnut & \multirow[t]{2}{*}{ Maize } & Bambara groundnut & \multirow[t]{2}{*}{ Maize } \\
\hline & Lead treatment & & Zinc treatment & \\
\hline & Mean value \pm SEM & Mean value \pm SEM & Mean value \pm SEM & Mean value \pm SEM \\
\hline Control & $14.79 \pm 0.44$ & $17.26 \pm 0.94$ & $14.79 \pm 0.09$ & $17.26 \pm 0.14$ \\
\hline 100 mg/kg & $17.60 \pm 0.01^{*}$ & $17.30 \pm 0.08^{*}$ & $6.75 \pm 0.2^{*}$ & $11.33 \pm 0.03^{*}$ \\
\hline 150 mg/kg & $12.10 \pm 0.02^{*}$ & $14.20 \pm 0.01^{*}$ & $5.98 \pm 0.02^{*}$ & $9.29 \pm 0.04^{*}$ \\
\hline 200 mg/kg & $11.20 \pm 0.02^{*}$ & $12.82 \pm 0.04^{*}$ & $5.11 \pm 0.07^{*}$ & $8.61 \pm 0.05^{*}$ \\
\hline 100 mg/kg + EDTA & $15.57 \pm 0.08^{*}$ & $9.17 \pm 0.03^{*}$ & $13.81 \pm 0.11^{*}$ & $12.86 \pm 0.11^{*}$ \\
\hline $150 \mathrm{mg} / \mathrm{kg}+\mathrm{EDTA}$ & $14.21 \pm 0.23^{*}$ & $8.64 \pm 0.01^{*}$ & $10.42 \pm 0.13^{*}$ & $9.54 \pm 0.05^{*}$ \\
\hline $200 \mathrm{mg} / \mathrm{kg}+\mathrm{EDTA}$ & $12.46 \pm 0.02^{*}$ & $7.62 \pm 0.01^{*}$ & $8.49 \pm 0.06^{*}$ & $8.47 \pm 0.04^{*}$ \\
\hline $100 \mathrm{mg} / \mathrm{kg}+$ manure & $17.58 \pm 0.06^{*}$ & $16.91 \pm 0.05^{*}$ & $17.81 \pm 0.05^{*}$ & $16.42 \pm 0.2^{*}$ \\
\hline $150 \mathrm{mg} / \mathrm{kg}+$ manure & $8.43 \pm 0.05^{*}$ & $7.05 \pm 0.21^{*}$ & $14.23 \pm 0.02^{*}$ & $7.22 \pm 0.05^{*}$ \\
\hline $200 \mathrm{mg} / \mathrm{kg}+$ manure & $7.36 \pm 0.03^{*}$ & $6.78 \pm 0.04^{*}$ & $9.42 \pm 0.04^{*}$ & $6.89 \pm 0.08^{*}$ \\
\hline
\end{tabular}

The values are the means + SEM (range) of 3 replicates

When ${ }^{*} P<0.05=$ significantly different from control

When $P>0.05=$ not significantly different from control

while the $100 \mathrm{mg} / \mathrm{kg}$ of lead and Manure gave 17.58 \pm 0.06. Maize control plants had $17.26 \pm 0.94$ mean percentage carbohydrate. Maize treated with $100 \mathrm{mg} /$ $\mathrm{kg}$ and $200 \mathrm{mg} / \mathrm{kg}$ of lead concentration had a mean percentage carbohydrate of $17.30 \pm 0.08$ and $12.82 \pm$ 0.04 , respectively. Maize plants with $200 \mathrm{mg} / \mathrm{kg}$ of lead and EDTA gave a mean percentage carbohydrate of $9.17 \pm 0.03$, while the $200 \mathrm{mg} / \mathrm{kg}$ of lead and manure gave $16.91 \pm 0.05$. The same trend was observed for the different zinc and lead concentrations on the mean total proteins of the two test plants. The statistical analysis, therefore, shows that the percentage of carbohydrates and proteins of treated plants were significantly different from their control $(p<0.05)$ for each tested crop plant.

\section{Discussion}

\subsection{Biochemical analysis}

Plant food generally contains abundant natural bioactive compounds that have health-promoting activities like antihypertensive, anti-inflammatory, and antioxidants, such bioactive compounds therefore include polyphenols [5]. However, when plants' biochemical activities are disrupted due to heavy metal exposure such benefits from the food (protein and carbohydrates) are therefore lost or reduced in plants. In the case of the study plants, the enzymatic activities of Bambara groundnut and Maize were adversely affected when the plants were exposed to different concentrations of lead and zinc. This was probably attributed to oxidative stress induced by these metals. For both test plants, there were increase and

Table 5 Effect of lead and zinc concentration on total protein of the test plants

\begin{tabular}{|c|c|c|c|c|}
\hline \multirow[t]{3}{*}{ Plants/concentration } & Bambara groundnut & Maize & Bambara groundnut & Maize \\
\hline & \multicolumn{2}{|l|}{ Lead treatment } & \multicolumn{2}{|l|}{ Zinc treatment } \\
\hline & Mean value \pm SEM & Mean value \pm SEM & Mean value \pm SEM & Mean value \pm SEM \\
\hline Control & $9.52 \pm 0.09$ & $6.46 \pm 1.0$ & $9.52 \pm 1.95$ & $6.46 \pm 1.26$ \\
\hline 100 mg/kg & $8.80 \pm 0.38^{*}$ & $5.89 \pm 1.05^{*}$ & $9.60 \pm 0.40^{*}$ & $5.16 \pm 0.55^{*}$ \\
\hline 150 mg/kg & $8.40 \pm 0.36^{*}$ & $5.63 \pm 1.0^{*}$ & $9.10 \pm 0.59^{*}$ & $5.04 \pm 0.59^{*}$ \\
\hline 200 mg/kg & $7.40 \pm 0.30^{*}$ & $5.08 \pm 0.64^{*}$ & $8.60 \pm 1.03^{*}$ & $4.96 \pm 0.13^{*}$ \\
\hline 100 mg/kg + EDTA & $10.09 \pm 0.25^{*}$ & $4.04 \pm 1.44^{*}$ & $10.12 \pm 0.84^{*}$ & $4.18 \pm 0.51^{*}$ \\
\hline 150 mg/kg + EDTA & $9.92 \pm 0.19^{*}$ & $3.84 \pm 0.35^{*}$ & $9.84 \pm 1.01^{*}$ & $4.12 \pm 0.45^{*}$ \\
\hline 200 mg/kg + EDTA & $9.80 \pm 0.16^{*}$ & $3.78 \pm 1.10^{*}$ & $9.72 \pm 1.47^{*}$ & $3.98 \pm 0.24^{*}$ \\
\hline $100 \mathrm{mg} / \mathrm{kg}+$ manure & $10.28 \pm 0.30^{*}$ & $4.12 \pm 0.51^{*}$ & $9.80 \pm 1.45^{*}$ & $5.56 \pm 0.32^{*}$ \\
\hline $150 \mathrm{mg} / \mathrm{kg}+$ manure & $9.68 \pm 0.25^{*}$ & $4.20 \pm 0.51^{*}$ & $9.64 \pm 0.75^{*}$ & $5.97 \pm 0.31^{*}$ \\
\hline 200 mg/kg + manure & $8.10 \pm 0.20^{*}$ & $4.80 \pm 0.95^{*}$ & $9.59 \pm 1.53^{*}$ & $6.12 \pm 0.54^{*}$ \\
\hline
\end{tabular}

The values are the means + SEM (range) of 3 replicates

When ${ }^{*} P<0.05=$ significantly different from control

When $P>0.05=$ not significantly different from control 
decrease in the level of the enzymes. The increased level of MDA (malondialdehyde) is highly indicative of oxidative stress for the plants. An increase in the level of MDA (product of lipid peroxidation) can lead to inactivation of enzymes, DNA damage, and interaction with vital plant cells. These results agreed with the work of Mansoor and Nasir [32] and Vazquez et al. [45]. The levels of glutathione, peroxidase, SOD, and catalase for the treated plants were also raised. The increased level of glutathione, peroxidase, and catalase also signifies the possible release of free radicals. This was again observed by Mansoor and Nasir [32]. The level of superoxide dismutase, catalase, peroxidase, and glutathione were lowered in Bambara groundnut, except for the MDA. The low level of superoxide dismutase signifies the possible release of radicals within the treated Bambara groundnut due to no inhibition of oxidation. Malar et al. [31] also reported that the activity of antioxidative enzymes, such as APX and POX, in water hyacinths (Eichhornia crassipes (Mart.), positively correlated with $\mathrm{Pb}$ treatment, while in the case of SOD and CAT enzymes increased up to $800 \mathrm{mg} / \mathrm{L}$ treatment and then slightly decreased at higher concentrations. Anee et al. [6] had a similar observation with fluctuating enzyme activities especially, decreased catalase activity when Sesamum indicum was subjected to the stress of different waterlogging durations. This indicates that stress levels increased with increased waterlogging.

Also, this could be due to low metal translocation potential displayed by the plants. It could also be suggested as a tolerance capacity displayed by Bambara nut to protect itself from oxidative damage. On the other hand, the lowered MDA content indicates toxicity/poisoning in the test plant. MDA is the end product of peroxidation of membrane lipids and it accumulates when the plants are subjected to oxidative stress [44]. Generally, free radical generation and membrane damage would be low in tolerant plants and thereby formation of lower levels of MDA content [39]. As a result, in this study, the comparatively lowered MDA content in test plants to $\mathrm{Pb}$ and $\mathrm{Zn}$ stress may assist its tolerant nature. These findings corroborated the earlier work by Dietz and Schnoor [17] that lead stress causes multiple direct and indirect effects on plant growth and metabolism and also alter some physiological processes. Edwards et al. [19] also observed that high internal levels of glutathione can be beneficial as a first response towards some of the effects exerted by pollutants. Cells are usually protected from reactive oxygen species by the combined action of enzymatic antioxidant systems like catalase, peroxidase, and non-enzymatic antioxidant like ascorbate, glutathione, and phenolic compounds [13, 19]. Glutathione (GSH), a precursor for phytochelatins (PCs) which are heavy-metal binding peptides, is known to be involved in heavy-metal tolerance and sequestration. GSH plays a central role in defense against oxidative stress and heavy metals. Lead compounds have been observed to bind less strongly to phytochelatins (PCS) unlike other metals like zinc due to larger ion radius ( $\mathrm{Pb}$, octahedral) and high coordination number $(\mathrm{Pb}, 6-8)$. This could be the reason for the greater $\mathrm{Pb}$ tolerance and uptake by Maize with or without augmentation and less $\mathrm{Pb}$ tolerance by Bambara groundnut. This could also be attributed to the great tolerance of $\mathrm{Zn}$ exhibited by the two plants.

\subsection{Chlorophyll content}

The chlorophyll content of treated plants reduced significantly with increased metal concentration especially for lead in all treated plants. As the concentration of metals increased, the quantity of total chlorophyll in the treated plants decreased. This led to a reduction in photosynthetic activities and an indication of stress. This finding therefore agrees with Chettri et al. [16] who reported a decrease in chlorophyll levels for Cladonia rangiformis after treating with $\mathrm{Cu}, \mathrm{Zn}$, and $\mathrm{Pb}$. They added that a decrease of chlorophyll after $\mathrm{Cu}$ application may be due to the blocking of enzymes acting in chlorophyll synthesis or to degradation of chlorophyll. They also said that chlorophyll content is usually measured in plants in order to assess the impact of environmental stress, as changes in pigment content are linked to visual symptoms of plant illness and photosynthetic productivity. The chlorophyll content reduced with increased zinc and lead nitrate concentrations [39]., had similar observations as experienced in this present study, with a reduction in chlorophyll and carotenoid content of cuttings and seedlings of Jatropha curcas L. under high concentration of lead $(\mathrm{Pb})$. Shu et al. [39] perceive chlorophyll degradation and photosynthesis inhibition as a specific response of plants to metal stress. The lowered content of chlorophyll specifies a decrease in net photosynthesis due to reduced absorption of essential mineral nutrients as an indirect reason for plant chlorosis. Lead $\mathrm{Pb})$ contamination induces leaf chlorosis and may eventually lead to cell death [37].

\subsection{Total carbohydrate and total protein}

The total protein and total carbohydrate of treated plants decreased significantly with increased lead and Zinc concentrations. However, farmyard manure assisted Bambara groundnut when planted in soil with manure mixed with the lowest lead concentrations of $100 \mathrm{mg} / \mathrm{kg}$ and different zinc nitrate concentrations. In support of these findings, several studies show that lead $(\mathrm{Pb})$ significantly affects nutrient uptake and overall distribution of nutritional elements within plant organs [9, 23, 49]. Chettri et al. [15], observed that lead ( $\mathrm{Pb})$ had an adverse effect on the metabolites content through protein in 
Vigna umbellata likewise carbohydrate in Phaeeolus vulgaris [24] at higher levels.

\section{Conclusion}

The results of this study suggest that $\mathrm{Pb}$ and $\mathrm{Zn}$ induce oxidative stress in treated plants. Elevated activity of anti-oxidative enzymes can assist as important components of an antioxidative defense mechanism against oxidative damage. The lowered enzymatic activities in Bambara nut suggested its tolerance capacity to protect it from oxidative damage. This could be the reason for the greater $\mathrm{Pb}$ tolerance by Maize with or without augmentation and less $\mathrm{Pb}$ tolerance by Bambara groundnut. This could also be attributed to the great tolerance of $\mathrm{Zn}$ exhibited by the two plants. Therefore, it can be said that both test plants can successfully tolerate $\mathrm{Zn}$ polluted soils.

\section{Abbreviations}

DNA: Deoxyribonucleic acid; EDTA: Ethylene diamine acetate; GSH: Glutathione synthetase; MDA: Malondialdehyde; Nm: Nanometer; RNA: Ribonucleic acid; SOD: Superoxide dismutase; UVNIS: Ultraviolet-visible spectrophotometry

\section{Acknowledgements}

N/A

\section{Authors' contributions}

EO corresponding author conceived of the study, participated in the design of the study, carried out heavy metal analysis, carried out statistical analysis, and presented the data. $\mathrm{O}$ participated in the design of the study, helped with the literature review and data analysis. YT participated in the design of the study, carried out the biochemical analysis in the study, and helped to draft the manuscript. IA participated in the design of the study, coordination and approved the final manuscript. All authors have read and approved the manuscript.

\section{Funding}

$\mathrm{N} / \mathrm{A}$

\section{Availability of data and materials}

All data generated or analyzed during this study are included in this published article.

\section{Ethics approval and consent to participate}

N/A

\section{Consent for publication}

N/A

\section{Competing interests}

The authors declare that they have no competing interests.

\section{Author details}

${ }^{1}$ Biology Unit, Distance Learning Institute, University of Lagos, Akoka, Lagos, Nigeria. ${ }^{2}$ Department of Biology, Federal University, Birnin-Kebbi, Kebbi, Nigeria. ${ }^{3}$ Department of Cell Biology and Genetics, University of Lagos, Akoka, Lagos, Nigeria.

Received: 4 July 2019 Accepted: 15 November 2019

Published online: 16 December 2019

\section{References}

1. Agbogidi OM (2010) Screening six cultivars of cowpea (Vigna unguiculata (L) Walp) for adaptation to soil contaminated with spent engine oil. Academic Arena 2(4):33-40
2. Agoda S, Atanda S, Usanga OE, Ikotun I, Isong IU (2011) Post-harvest food losses reduction in Maize production in 'Nigeria. African Journal of Agricultural Research 6:4833-4839

3. Alscher RG, Donahue JL, Cramer CL (1997) Reactive oxygen species and antioxidants: relationship in green cells. Physiology of Plants 100:224-233

4. Alscher RG, Erturk N, Heath LS (2002) Role of superoxide dismutases (SODs) in controlling oxidative stress in plants. Journal of Experimental Botany 53: $1331-1341$

5. Amarowicz R, Pegg RB, Rahimi-Moghaddam P, Bari B, Weil JA (2004) Freeradical Scavenging capacity and antioxidant activity of selected plant species from the Canadian parities. Food Chem. 84:551-562

6. Islam AT, Kamrun N, Anisur R, Jubayer AM, Farha BT, Mazhar UA, Masayuki F, Mirza H (2019) Oxidative Damage and Antioxidant Defense in Sesamum indicum after Different Waterlogging Durations. Plants 8(7):196. https://doi. org/10.3390/plants8070196

7. Arnon DI (1949) Copper enzymes in isolated chloroplasts polyphenol oxidase in Beta vulgaris. Plant Physiology 24:1-15

8. Artenie, V., Ungureanu, E., Negura, A.M., 2008. Method of Investigating lipid peroxidation and metabolism. Practice manual. $2^{\text {nd }}$ Edition $182 \mathrm{p}$

9. Arshad M, Silvestre J, Pinelli E, Kallerhoff J, Kaemmerer M, Tarigo A, Shahid M, Guiresse M, Pradere P, Dumat C (2008) A field study of lead phytoextraction by various scented Pelargonium cultivars. Chemosphere 71(11):2187-2192

10. ASTDR (2003): Agency for Toxic Substances and Disease Registry. http:// www.astdr.cdc.gov

11. Azmat R, Hassan (2007) Photochemistry of light harvesting pigments and some biochemical changes under Aluminium stress. Pakistan Journal of Botany 40(2):779-784

12. Baccio, D., Kopriva,S., Sebastiani ,L. and Rennenberg, H. (2005).Does glutathione metabolism have a role in the defiance of poplar against zinc excess. New Phytol. 167:73-80.

13. Balasundram N, Samman S (2006) Phenolic compounds in plants and agriindustrial by- products: antioxidant activity, occurrence and potential uses. Food Chem 99:191-203

14. Chao WH, Askew EW, Wood DE, Perkins JB (1999) Oxidative stress in humans during work at moderate altitude. Journal of Nutrition 129:2009_ 2012

15. Cheetri DR, Supratin M, Safiruddin A (2004) Physiological and Biochemical Response of two rice bean (Vigna umbellaata) cultivars to heavy metal stress. Environment and Ecology 22:27-33

16. Chettri MK, Cook CM, Vardaka E, Sawidis T, Lanaras T (1998) The effect of $\mathrm{Cu}, \mathrm{Zn}$ and $\mathrm{Pb}$ on the chlorophyll content of the lichens Cladonia convoluta and Cladonia rangiformis. Environmental and Experimental Botany 39:1-10

17. Dietz A, Schnoor JL (2001) Advances in phytoremediation. Environmental Perspectives 109:163-168

18. DuBois M, Gilles KA, Hamilton JK, Rebers PA, Smith F (1956) Colorimetric method for determination of sugars and related substances. Anal. Chem. 28: 350-356

19. Edwards R, Dixon DP, Walbot V (2000) Plant glutathione S-transferases: enzymes with multiple functions in sickness and health. Trends. Plant Science 5(5):193-198

20. Fales FW (1951) The Assimilation and Degradation of Carbohydrates of Yeast cells. Biological Chemistry 193:113-118

21. Grover P, Rekhadevi P, Danadevi K, Vuyyuri S, Mahboob M, Rahman M (2010) Genotoxicity evaluation in workers occupationally exposed to lead. Int J Hyg Environ Health 213(2):99-10

22. Gornell AG, Bradawill CJ, David MM (1949) Detrmination of serum proteins by means of the biuret reaction. Journal of Biology and Chemistry. 177:751-766

23. Gopal R, Rizvi AH (2008) Excess lead alters growth, metabolism and translocation of certain nutrients in radish. Chemosphere 70:1539-1544

24. Hammed N, Bukhari N, Faiza Jawaid F (2010) Physiological responses of Phaseolus vulgaris to different lead concentrations. Pakistan Journal of Botany. 42:239-246

25. Hiner A, Raven E, Thorneley R, García-Cánovas F, Rodríguez-López J (2002) Mechanisms of compound I formation in heme peroxidases. Journal of Inorganic Biochemistry 1:27-34

26. Jollow DJ, Michelle JR, Zampaglione N, Gillete JR (1974) Bromobenzene induced liver necrosis protective role of GSH and evidence for 3,4Bromobenzene oxideas the Hepatotoxic metabolite. Pharmacology. 11: $151-169$ 
27. Lang CA (1958) Simple microdetermination of Kjeldhal nitrogen in biological materials. Analytical Chemistry 30:1692-1694

28. Lone MI, He Z, Stoffella PJ, Yang X (2008) Phytoremediation of heavy metal polluted soils and water: Progresses and perspectives. Journal of Zhejiang Unversity Science B 9:210-220

29. Maestri E, Marmiroli M, Visioli G, Marmiroli N (2010) Metal tolerance and hyperaccumulation: costs and trade-offs between traits and environment. Environ Exp

30. Magwere T, Naiks YS, Hasler JA (1997) Effects of chloroquine treatment on antioxidant enzymes in rat liver and kidney. Free radical Biol. Med 22:321-327

31. Malar Srinivasan, Vikram Sahi Shivendra, JC Favas Paulo and Perumal Venkatachalam (2016). Lead heavy metal toxicity induced changes on growth and antioxidative enzymes level in Water Hyacinths (Eichhornia crassipes (Mart.) Botanical Studies.55: 54

32. Simeen M, Farzana NN (2013) Effect of heat stress on lipid peroxidation and antioxidant enzymes in mung bean (Vigna radiata L) seedlings. African Journal of Biotechnology 12(21):3197-3202pp

33. Nakano Y, Asada K (1981) Hydrogen peroxide is scavenged by ascorbatespecific peroxidases in spinach chloroplasts. Plant and Cell Physiology 22: 867-880

34. Niazi JH, Sang Bl, Kim YS, Gu MB (2011) Global gene response in saccharomycetes cerevisiae exposed to silver nanoparticles. Applied Biochemistry Biotechnology 164(8):1278-1284

35. Noctor G, Foyer CH (1998) Ascorbate and glutathione: keeping active oxygen under control. Annual Review of Plant Physiology and Plant Molecular Biology 49:249-279. https://doi.org/10.1146/annurev.arplant.49.1.249

36. Oyewo IO (2011) Technical Efficiency of Maize Production in Oyo State. Journal of Economics and International Finance 3:211-216

37. Seregin IV, Shpigun LK, Ivanio VB (2004) Distribution and toxic effects of cadmium and lead on Maize roots. Russian Journal of Plant Physiology 51: 525-533

38. Shahid M, Pinelli E, Pourrut B, Silvestre J, Dumat C (2011) Lead-induced genotoxicity to Vicia faba L. roots in relation with metal cell uptake and initial speciation. 4(1):78-84

39. Shu X, Yin L, Zhang Q, Wang W (2011) Effect of Pb toxicity on leaf growth, Antioxidant enzyme activities and photosynthesis in cuttings and seedlings of Jatropha curcas L

40. Sinha AK (1972) Colorimetric assay of catalase. Anaytical Biochemistry 47 389-394

41. United States Agency for International Development (USAID) (2011) Package of practices for Maize production, Washington DC, pp 1-23

42. U.S. Agency for International Development http://www.usaid.gov/ evaluation. 1300.Pennysylvania Avenue, Nw, Washington,DC 20523.

43. Uzu G, Sobanska S, Sarret G, Munoz M, Dumat C (2010) Foliar lead uptake by lettuce exposed to atmospheric fallouts. Environ Science Technology 44: 1036-1042

44. Varsheney, R and Kale R.K. 2007. Modulation of radiation induced lipid peroxidation by phospholipase $\mathrm{A}_{2}$ and calmodulin antagonists: Relevance to detoxification African Journal of Biotechnology 6(3): 175-178.

45. Vazquez MD, Poschenrieder C, Barcelo J (1987) Chromium (VI) induced structural and Ultrastructural changes in bush bean plants (Phaseolus vulgaris). Ann Bot 59:427-438

46. Waisberg M, Joseph P, Hale B, Beyersmann D (2003) Molecular and cellular mechanisms of cadmium carcinogenesis. Toxicology 192:95-117

47. WHO (1995) Inorganic Lead. In: Environmental Health Criteria 165. World Health Organization, Geneva

48. Wu P, Liao CY, Hu B, Yi KK, Jin WZ, Ni JJ, He C (2000) QTLs and Epistasis for Aluminum Tolerance in Rice (Oryza sativa L.) at different seedling stages. Theoretical and Applied Genetics 100:1295-1303

49. Zhong B, Chen J, Shafi M, Guo Y, Wang Y, Wu J, Zhengqian H, Lizhi H, Liu D (2017) Effect of lead (Pb) on antioxidation system and accumulation ability of Moso bamboo (Phyllostachys pubescens). Ecotoxicology and Environmental Safety 138:71-77

\section{Publisher's Note}

Springer Nature remains neutral with regard to jurisdictional claims in published maps and institutional affiliations.

\section{Submit your manuscript to a SpringerOpen ${ }^{\circ}$ journal and benefit from:}

- Convenient online submission

- Rigorous peer review

- Open access: articles freely available online

- High visibility within the field

- Retaining the copyright to your article

Submit your next manuscript at $\boldsymbol{\nabla}$ springeropen.com 